\title{
Laskeutusallas-kosteikosta poistettavan sedimentin peltolevitys - Onko maatalouden kosteikkosedimentin fosforista kasvinravinteeksi?
}

\author{
Johanna Laakso ${ }^{1)}$, Risto Uusitalo ${ }^{2)}$ ja Markku Yli-Halla ${ }^{1)}$ \\ ${ }^{1)}$ Elintarvike- ja ympäristötieteiden laitos, PL 27, Latokartanonkaari 11, 00014 Helsingin yliopisto, \\ johanna.m.laakso@helsinki.fi,markku.yli-halla@helsinki.fi \\ ${ }^{2)}$ MTT, Kasvintuotannon tutkimus, Planta, 31600 Jokioinen, risto.uusitalo@mtt.fi
}

\section{Tiivistelmä}

Maatalouden vesiensuojelussa käytettäviin laskeutusaltaisiin kertyy sedimenttiä, johon on sitoutunut runsaasti partikkelimuotoista fosforia. Fosfori on peräisin viljelysmaista, joista valunnan mukana kulkeutuu eroosioainesta kohti vesistöjä. Maatalouskosteikosta sedimentti on poistettava aika ajoin, ja se suositellaan levitettäväksi takaisin peltoon, mikä tukee pyrkimystä suljetumpaan ravinnekiertoon. Epäilykset sedimentin soveltuvuudesta kasvualustaksi ja yleinen keskustelu fosforivarojen riittävyydestä ovat synnyttäneet tarpeen tämän tutkimuksen tekemiseksi. Tässä MMM:n rahoittamassa hankkeessa selvitetään maatalouskosteikoiden sedimentissä tapahtuvaa fosforin pidättymistä ja vapautumista sekä sedimentin hyötykäyttömahdollisuuksia.

Tutkimuskohteina oli kaksi savimaan maatalouskosteikkoa: Liedonperä (Tarvasjoki) ja Ojainen (Jokioinen). Sedimentin käyttökelpoisuutta kasvualustana tutkittiin astiakokeessa, jossa kosteikkosedimentin ja valuma-alueen peltomaan seoksia (sedimenttiä $0 ; 12,5 ; 25$ ja $50 \%$ ) käytettiin raiheinän kasvatukseen kasvihuoneessa. Raiheinästä korjattiin kolme satoa, joista määritettiin kasvin kuiva-ainesato ja fosforinotto. Astiakokeen tueksi sedimenttinäytteistä ja lähivaluma-alueen peltomaanäytteistä analysoitiin perusominaisuudet ja fosforin fraktiot. Analyysit tehtiin sekä tuoreista että kuivatuista sedimenteistä, jotta saataisiin käsitys peltolevityksessä kuivuvan sedimentin ominaisuuksista.

Astiakoe osoitti sedimentin pidättävän kasveille käyttökelpoista fosforia kasvien ulottumattomiin. Mitä enemmän sedimenttiä oli kasvualustassa, sitä pienempi kasvin fosforinotto oli runsaasta fosforilannoituksesta huolimatta. Kun kasvualusta sisälsi 12,5\% sedimenttiä, kasvin fosforinotto väheni 6 $50 \%$ verrattuna pelkässä peltomaassa kasvaneen kasvin fosforinottoon. Fosforinoton väheneminen havaittiin myös lannoittamattomilla kasveilla. Lannoittamaton raiheinä kärsi ankarasta fosforinpuutoksesta ( $\mathrm{P}<1 \mathrm{mg}$ $\mathrm{g}^{-1}$ kasvin kuiva-ainetta), kun kasvualustassa oli $50 \%$ sedimenttiä.

Sedimentin suuri fosforinpidätyskyky johtui todennäköisesti siitä, että sedimentissä oli fosforia pidättäviä raudan- ja alumiininoksideja kaksinkertaisesti verrattuna valuma-alueen peltomaahan. Astiakoetta tukevat analyysit viittasivat kosteikkosedimentin suureen fosforireserviin, jonka saatavuus riippuu pitkälti raudan hapetus-pelkistystilasta. Kosteikkosedimentistä vapautui hapellisissa olosuhteissa tuoreena jopa kuusinkertaisesti helppoliukoista fosforia (Liedonperä 41 ja Ojainen $240 \mathrm{mg} \mathrm{kg}^{-1}$ maata) verrattuna kuivaan sedimenttiin $\left(30\right.$ ja $\left.61 \mathrm{mg} \mathrm{kg}^{-1}\right)$ tai peltomaahan $\left(26 \mathrm{ja} 67 \mathrm{mg} \mathrm{kg}^{-1}\right)$. Sedimentissä on myös suuri hapettomissa olosuhteissa mahdollisesti vapautuva fosforireservi $\left(226 \mathrm{ja}^{6} 68 \mathrm{mg} \mathrm{kg}^{-1}\right)$.

Sedimentti ei sellaisenaan sovellu kasvualustaksi, eikä sen peltolevityksestä ole kasvinravitsemuksellista hyötyä. Seuraavaksi tässä tutkimuksessa selvitetään sedimentin soveltuvuutta fosforinsidontaan runsaasti helppoliukoista fosforia sisältävillä mailla.

Asiasanat: fosfori, kasveille käyttökelpoinen fosfori, sedimentti, kosteikko, laskeutusallas, kasvinravinne, astiakoe, raiheinä 


\section{Johdanto}

Maatalouden laskeutusallas-kosteikoiden avulla pyritään vähentämään pelloilta vesistöihin joutuvaa eroosioaineksen määrää ja ravinnekuormitusta. Altaiden syvänteisiin kertyy sedimenttiä, johon on sitoutunut runsaasti partikkelimuotoista fosforia. Fosfori on peräisin viljelysmaista, joista valunnan mukana kulkeutuu eroosioainesta kohti vesistöjä. Laskeutusallas-kosteikoihin kertynyt liete on poistettava käytännössä $2-5$ vuoden välein ennen kuin sille varattu tila täyttyy. Liete suositellaan levitettäväksi takaisin pelloille (Puustinen ym. 2007, s. 69), mikä tukee pyrkimystä suljetumpaan ravinnekiertoon. Epäilykset sedimentin soveltuvuudesta kasvualustaksi ja yleinen keskustelu fosforivarojen riittävyydestä ovat synnyttäneet tarpeen tämän tutkimuksen tekemiseksi.

Tässä kolmivuotisessa (8/2012-10/2015), MMM:n rahoittamassa tutkimuksessa selvitetään maatalouskosteikoiden sedimentissä tapahtuvaa fosforin pidättymistä ja vapautumista, ja siihen vaikuttavia tekijöitä muuttuvissa olosuhteissa, esimerkiksi sedimentin peltolevityksessä. Keskeisenä tutkimuskohteena on kosteikkosedimenttien fosforisisältö, erityisesti kasveille käyttökelpoiset fosforin fraktiot. Käytännön sovellutuksena selvitetään sedimentin hyötykäyttömahdollisuuksia esimerkiksi kasvualustana.

\section{Aineisto ja menetelmät}

Laskeutusallas-kosteikoiksi valittiin kaksi savimaalle perustettua maatalouskosteikkoa: Liedonperän kosteikko (Tarvasjoki) ja Ojaisten kosteikko (Jokioinen). Tutkimuskosteikoiden koko ja taustatiedot on esitetty taulukossa 1 . Kosteikoista otettiin sedimenttinäytteet $(0-17 \mathrm{~cm})$ ja lähivaluma-alueen peltomaasta maanäytteet $(0-20 \mathrm{~cm})$.

Taulukko 1. Tiedot laskeutusallas-kosteikoista.

\begin{tabular}{|l|l|l|l|l|l|l|}
\hline $\begin{array}{l}\text { Kohde } \\
\text { (Sijaintikunta) }\end{array}$ & $\begin{array}{l}\text { Perustamis- } \\
\text { vuosi }\end{array}$ & $\begin{array}{l}\text { Kosteikon } \\
\text { koko }\end{array}$ & Valuma-alue & $\begin{array}{l}\text { Kosteikon } \\
\text { koko/valuma- } \\
\text { alue }\end{array}$ & Peltoprosentti & $\begin{array}{l}\text { Saves valuma- } \\
\text { alueella }\end{array}$ \\
\hline & & $\mathrm{m}^{2}$ & $\mathrm{~km}^{2}$ & $\%$ & $\%$ & $\%$ \\
\hline $\begin{array}{l}\text { Liedonperä } \\
\text { (Tarvasjoki) }\end{array}$ & 1995 & 4850 & 0,99 & 0,49 & 50 & 34,8 \\
\hline $\begin{array}{l}\text { Ojainen } \\
\text { (Jokioinen) }\end{array}$ & 2000 & 370 & 0,16 & 0,24 & 100 & 45,4 \\
\hline
\end{tabular}

Analyysien tarkoitus oli kuvata eroosioaineksen fosforisisältöä ja ominaisuuksia muuttuvissa olosuhteissa; peltomaa -> lasketusaltaan pohjasedimentti -> ruopattu aines pellolla. Analysoitavat näytteet olivat:

- Maanäyte lähivaluma-alueelta, joka kuvaa sedimentin lähtöaineksen ominaisuuksia peltomaassa

- Tuore, osittain pelkistynyt sedimentti, joka kuvaa olosuhteita kosteikon pohjalla

- Hapettunut, kuivunut sedimentti, jolla luonnehditaan sedimentin ominaisuuksia peltolevityksen jälkeen

Näytteiden ominaisuuksia vertaamalla saatiin käsitys siitä, mitä tapahtuu maapartikkeliin sitoutuneelle fosforille, kun 1) pellossa oleva maapartikkeli lähtee valumaveden mukana kulkeutumaan kohti laskeutusallasta (tai vesistöä), 2) partikkeli laskeutuu altaan pohjalle ja olosuhteet muuttuvat mahdollisesti hapettomiksi (pelkistyneiksi) ja 3) ruopattu maa-aines hapettuu uudelleen.

Tutkimusmenetelminä olivat erilaiset uutot, joilla määritettiin sedimentistä/peltomaasta eri olosuhteissa nesteeseen vapautuvan fosforin pitoisuuksia. Anioninvaihtohartsiuutto (Sibbesen 1978, Uusitalo \& Ekholm 2003) ja bikarbonaatti-ditioniittiuutto (Uusitalo \& Turtola 2003) kuvaavat potentiaalisesti liukenevan fosforin määrä hapellisissa ja hapettomissa olosuhteissa. Maan ja sedimentin alumiinin ( $\mathrm{Al})$ ja raudan $(\mathrm{Fe})$ oksidien pitoisuudet (fosforin sorptiokomponentit) määritettiin happamalla ammoniumoksalaattiuutolla (Schwertmann 1964). Näytteiden epäorgaaninen fosfori fraktioitiin modifioidulla Changin ja Jacksonin menetelmällä (helppoliukoinen - Al:n sitoma - Fe:n sitoma - apatiittinen) (Hartikainen 1979). Näytteistä analysoitiin myös kokonaisfosfori, kokonaistyppi, kokonaishiili, nk. viljavuusfosfori (hapan ammoniumasetaattiuutto), $\mathrm{Ca}, \mathrm{Mg}, \mathrm{K}, \mathrm{S}$, lajitekoostumus eli partikkelikokojakauma sekä pH.

Sedimentin sisältämän fosforin käyttökelpoisuutta kasveille tutkittiin astiakokeessa kasvihuoneessa, jossa oli valon ja lämpötilan suhteen vakioidut olosuhteet. Tutkimuskosteikoiden sedimenttiä ja valuma- 
alueen peltomaata sekoitettiin neljässä eri seossuhteessa; sedimenttiä $0 \% ; 12,5 \% ; 25 \%$ ja $50 \%$. Peltomaasedimentti-seokseen lisättiin $200 \mathrm{~g}$ kvartsihiekkaa kasvualustan rakenteen parantamiseksi. Ruukut jaettiin kahteen osaan, $\mathrm{P} 0$ ja $\mathrm{P} 150$, joista ensimmäiset eivät saaneet $\mathrm{P}$-lannoitusta ja jälkimmäiset saivat $\mathrm{P}$ lannoituksen $150 \mathrm{mg} \mathrm{P} \mathrm{kg}^{-1}$ kuiva-ainetta. Kaikki ruukut saivat lisäksi $\mathrm{N}-, \mathrm{K}-, \mathrm{Mg}-$ ja S-lannoituksen. Ruukkuihin kylvettiin raiheinää (Lolium multiflorum). Raiheinästä korjattiin kolme satoa, joista ensimmäinen 30 vrk, toinen 50 vrk ja kolmas sato 70 vrk kylvöstä. Korjatusta kasviaineksesta määritettiin fosforipitoisuus ja kuiva-ainesadon perusteella laskettiin kasvin fosforin otto.

\section{Tulokset ja tulosten tarkastelu}

Astiakoe osoitti sedimentin pidättävän kasveille käyttökelpoista fosforia raiheinän ulottumattomiin. Fosforin oton väheneminen havaittiin sekä P-lannoitetuilla että ilman P-lannoitusta kasvaneilla kasveilla. Kun kasvualusta sisälsi 12,5\% sedimenttiä, kasvin fosforin otto laski P:lla lannoittamattomassa kasvuseoksessa 6 - $50 \%$, ja P-lannoitetussa vastaavasti $6-17 \%$, verrattuna pelkässä peltomaassa kasvaneen kasvin fosforin ottoon (Kuvat 1 ja 2). Mitä enemmän sedimenttiä oli kasvualustassa, sitä pienempi kasvin fosforin otto oli runsaasta fosforilannoituksesta huolimatta. Kun kasvualustassa oli $50 \%$ sedimenttiä, P-lannoitetun raiheinän fosforin otto väheni 28 - $43 \%$ (Kuva 2) ja P:llä lannoittamattoman jopa $75 \%$ (Kuva 1, Liedonperä 1. sato). Raiheinässä havaittiin ensimmäisiä fosforinpuutosoireita, kun P:lla lannoittamattomassa kasvualustassa oli $12,5 \%$ sedimenttiä. Puutosoireet yleistyivät toisessa ja kolmannessa sadossa sekä sedimenttipitoisuuden kasvaessa.

Sedimentin suuri fosforinpidätyskyky johtui todennäköisesti sen suuresta savespitoisuudesta; $62 \%$ Liedonperällä ja $82 \%$ Ojaisilla, kun peltomaassa vastaavat savespitoisuudet olivat $35 \%$ ja $45 \%$. Savesfraktio sisältää fosforia pidättäviä Al- ja Fe-oksideja, joilla on hyvin suuri ominaispinta-ala ja ne muodostavat maahiukkasten pinnoilla reaktiivista pintaa fosfaattianionin pidätykselle. Fe- ja Al-oksidien määrä oli suurempi sedimentissä kuin peltomaassa (Taulukko 2) ja niiden määrän havaittiin edelleen kasvavan sedimentin kuivuessa ja hapettuessa. Fosforin fraktiointi osoitti sedimentissä olevan fosforin sitoutuneen pitkälti Fe-oksideihin (Taulukko 2, NaOH-P), jolloin fosforin vapautuminen tai sitoutuminen maapartikkeliin riippuu hapetus-pelkistys-olosuhteista. Tähän viittaa myös sedimentin suuri pelkistyneissä olosuhteissa vapautuva fosforipitoisuus. Kokonaisfosforipitoisuus oli lähes samansuuruinen sedimentissä ja peltomaassa.

Osittain vielä pelkistyneestä, tuoreesta Ojaisten kosteikkosedimentistä vapautui hapellisissa olosuhteissa jopa kuusinkertaisesti AER-uuttoista fosforia (240 mg kg${ }^{-1}$ maata) verrattuna hapettuneeseen, kuivaan sedimenttiin (61 mg kg-1) tai peltomaahan $\left(67 \mathrm{mg} \mathrm{kg}^{-1}\right.$ ) (Kuva 3). AER-uuttoisen fosforin on osoitettu olevan helppoliukoista ja suoraan leville käyttökelpoista (Uusitalo \& Ekholm 2003). Tulos kertoo muuttuvien olosuhteiden tärkeästä merkityksestä fosforin sitoutumiseen/vapautumiseen maa - kasvi - vesi systeemissä. Peltomaassa fosforia oli sitoutuneena Al-oksideihin (Taulukko 2, $\mathrm{NH}_{4} \mathrm{~F}-\mathrm{P}$ ). Tämän fraktion on todettu ensisijaisesti säätelevän kasveille käyttökelpoisen fosforin pitoisuutta maassa, kun taas sedimentissä kyseinen fraktio oli puolittunut. Täten kasveille käyttökelpoista fosforia oli ilmeisesti vapautunut maapartikkelista vesieroosion seurauksena.

Kosteikon sedimentissä fosfori oli sitoutunut pääosin Fe-oksideihin (Taulukko 2, NaOH-P), jonka mobiilisuus riippuu hapetus-pelkistys -olosuhteista. Sedimentissä fosforia sitova $\mathrm{Fe}(\mathrm{III})$ pelkistyy hapettomissa olosuhteissa liukoiseksi Fe(II):ksi, jolloin siihen pidättynyttä fosforiakin liukenee. Sedimentin hapettuessa uudelleen, esimerkiksi pellolle levitettäessä, liukoinen rauta saostuu Fe(III)-oksideiksi maahiukkasten pinnoille ja saattaa lisätä maa-aineksen fosforinsitomiskykyä huomattavasti.

Sedimentti- ja peltomaanäytteissä erottui suomalaisille maille tyypillinen suuri apatiittisen fosforin määrä (Taulukko 2, $\mathrm{H}_{2} \mathrm{SO}_{4}-\mathrm{P}$ ). Apatiittinen fosfori on rakenteellista, vain hitaasti rapautumalla vapautuvaa fosforia, jolla ei ole välitöntä kasvinravitsemuksellista merkitystä (Kaila 1964). 


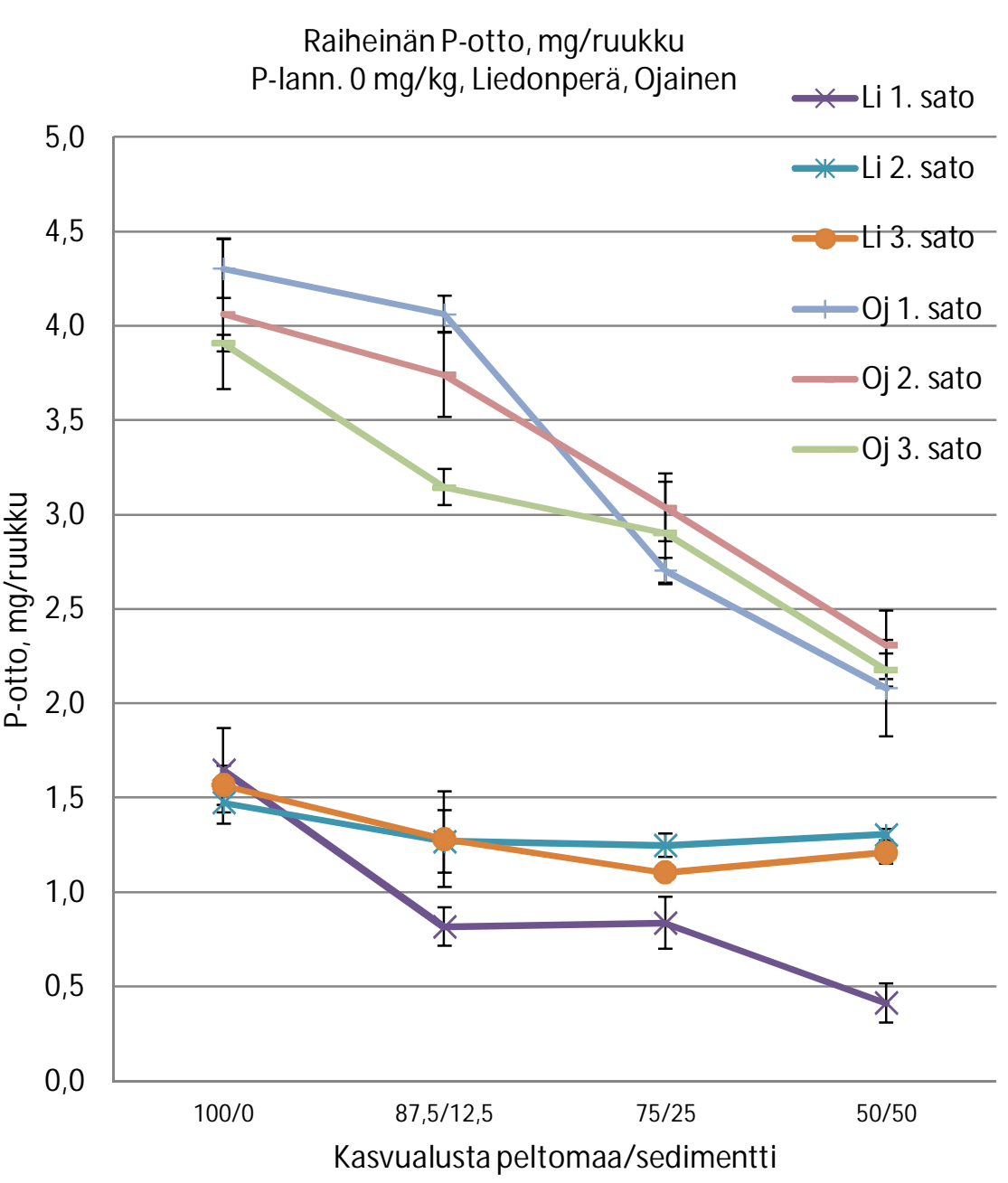

Kuva 1. Raiheinän satokohtainen fosforin otto (mg/astia) Liedonperän (Li) ja Ojaisten (Oj) peltomaa/sedimentti-kasvualustassa fosforilannoituksella $0 \mathrm{mg} \mathrm{kg}^{-1}$. Virhepalkit kuvaavat keskihajontaa $(n=3)$.

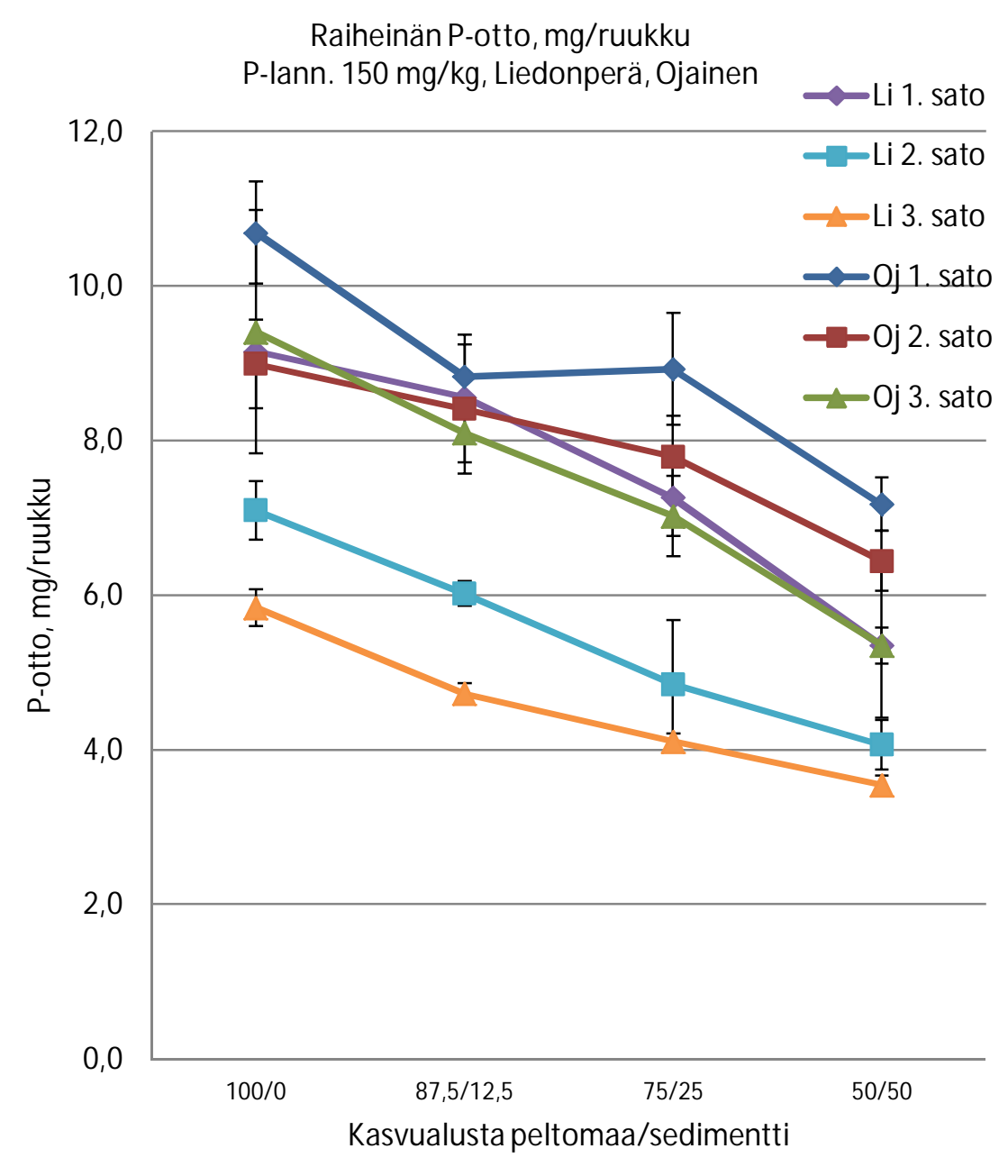

Kuva 2. Raiheinän satokohtainen fosforin otto (mg/astia) Liedonperän (Li) ja Ojaisten (Oj) peltomaa/sedimentti-kasvualustassa fosforilannoituksella $150 \mathrm{mg} \mathrm{kg}$ 1. Virhepalkit kuvaavat keskihanjontaa $(n=3)$. 
Taulukko 2. Chang \& Jacksonin fosforifraktiot $\left(\mathrm{NH}_{4} \mathrm{Cl}-\mathrm{P}, \mathrm{NH}_{4} \mathrm{~F}-\mathrm{P}, \mathrm{NaOH}-\mathrm{P}, \mathrm{H}_{2} \mathrm{SO}_{4}-\mathrm{P}\right)$, hapettomissa olosuhteissa vapautuva fosfori bikarbonaatti-ditioniittiuutolla (BD-P), kokonaisfosforipitoisuus (TP) sekä alumiinin ja raudan oksidien pitoisuudet happamalla ammoniumoksalaattiuutolla $\left(\mathrm{Al}_{\mathrm{ox}} \mathrm{ja} \mathrm{Fe}_{\mathrm{ox}}\right)$ peltomaassa sekä tuoreessa ja hapettuneessa sedimentissä. Tulokset ilmoitettu keskiarvo \pm keskivirhe.

\begin{tabular}{|c|c|c|c|c|c|c|c|c|}
\hline \multirow[t]{2}{*}{ Kosteikko } & \multicolumn{4}{|c|}{ Fosforin fraktiot } & \multirow[t]{2}{*}{ BD-P } & TP & $\mathrm{Al}_{\mathrm{ox}}$ & $\mathrm{Fe}_{\mathrm{ox}}$ \\
\hline & $\mathrm{NH}_{4} \mathrm{Cl}-\mathrm{P}$ & $\mathrm{NH}_{4} \mathrm{~F}-\mathrm{P}$ & $\begin{array}{c}\mathrm{NaOH}-\mathrm{P} \\
\mathrm{kg}^{-1}\end{array}$ & $\mathrm{H}_{2} \mathrm{SO}_{4}-\mathrm{P}$ & & $\mathrm{ng} \mathrm{kg}^{-1}$ & \multicolumn{2}{|c|}{$\mathrm{mmol} \mathrm{kg}$} \\
\hline & Peltomaa & & & & & & & \\
\hline $\begin{array}{l}\text { Ojainen } \\
\text { Liedonperä }\end{array}$ & $\begin{array}{l}0,3 \pm 0,2 \\
0,4 \pm 0,2\end{array}$ & $\begin{array}{c}132 \pm 12 \\
51 \pm 14\end{array}$ & $\begin{array}{l}366 \pm 30 \\
184 \pm 39\end{array}$ & $\begin{array}{l}222 \pm 33 \\
284 \pm 12\end{array}$ & - & $\begin{array}{c}1450 \pm 103 \\
993 \pm 79\end{array}$ & $\begin{array}{c}112 \pm 5 \\
93 \pm 1\end{array}$ & $\begin{array}{c}223 \pm 11 \\
191 \pm 2\end{array}$ \\
\hline & \multicolumn{4}{|c|}{$\underline{\text { Tuore, osittain pelkistynyt sedimentti }}$} & & & & \\
\hline $\begin{array}{l}\text { Ojainen } \\
\text { Liedonperä }\end{array}$ & $\begin{array}{c}0,6 \pm 0,0 \\
0 \pm 0\end{array}$ & $\begin{array}{l}71 \pm 8 \\
20 \pm 2\end{array}$ & $\begin{array}{l}544 \pm 6 \\
190 \pm 5\end{array}$ & $\begin{array}{l}117 \pm 36 \\
243 \pm 16\end{array}$ & $\begin{array}{l}698 \pm 2 \\
226 \pm 17\end{array}$ & - & $\begin{array}{l}181 \pm 28 \\
124 \pm 11\end{array}$ & $\begin{array}{l}253 \pm 31 \\
315 \pm 48\end{array}$ \\
\hline & \multicolumn{4}{|c|}{$\underline{\text { Hapettunut, kuivunut sedimentti }}$} & & & & \\
\hline $\begin{array}{l}\text { Ojainen } \\
\text { Liedonperä }\end{array}$ & $\begin{aligned} 0,2 & \pm 0,0 \\
0 & \pm 0\end{aligned}$ & $\begin{array}{l}76 \pm 8 \\
10 \pm 2\end{array}$ & $\begin{array}{c}450 \pm 41 \\
172 \pm 4\end{array}$ & $\begin{array}{l}174 \pm 26 \\
279 \pm 21\end{array}$ & $\begin{array}{l}197 \pm 17 \\
235 \pm 10\end{array}$ & $\begin{array}{l}1467 \pm 6 \\
972 \pm 12\end{array}$ & $\begin{array}{l}292 \pm 5 \\
186 \pm 2\end{array}$ & $\begin{array}{l}261 \pm 3 \\
351 \pm 4\end{array}$ \\
\hline
\end{tabular}

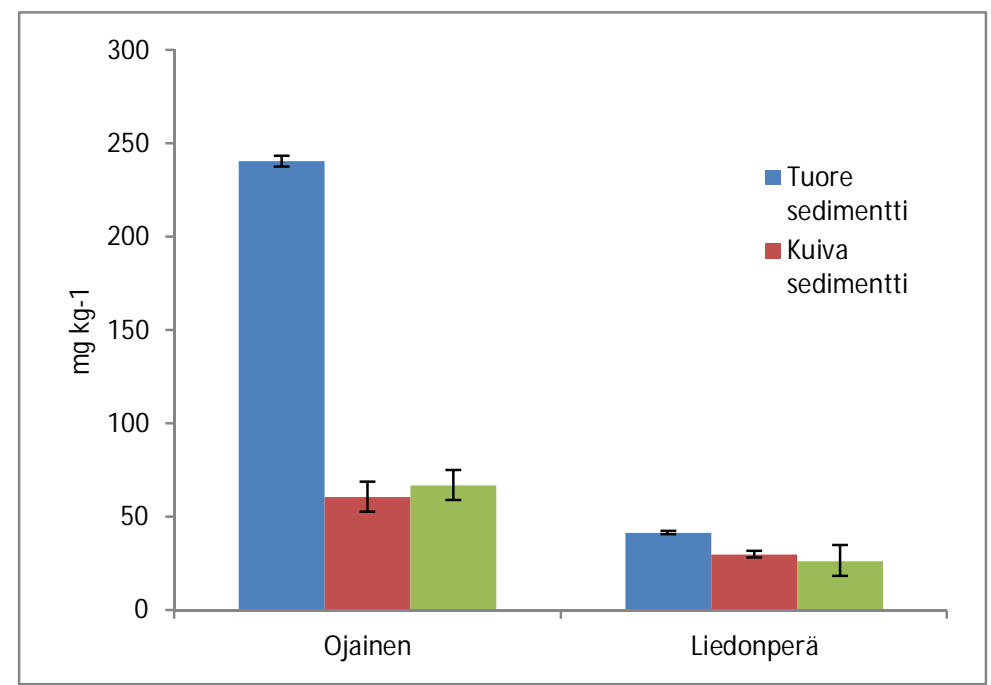

Kuva 3. AER-uutoinen fosfori eli hapellisissa olosuhteissa vapautuvan fosforin määrä $\left(\mathrm{mg} \mathrm{kg}^{-1}\right)$ tuoreissa (osittain pelkistyneissä) sedimenttinäytteissä, hapettuneessa (kuivuneessa) sedimentissä sekä peltomaassa. Virhepalkit kuvaavat keskivirhettä $(n=3)$.

\section{Johtopäätökset}

Laskeutusallas-kosteikon sedimentti pidättää kasvualustassa helppoliukoista fosforia kasvien ulottumattomiin. Mitä enemmän sedimenttiä kasvualustassa oli, sitä pienempi kasvin fosforin otto oli runsaasta fosforilannoituksesta huolimatta. Sedimentti ei sellaisenaan sovellu kasvualustaksi, eikä sen peltolevityksestä ole kasvinravitsemuksellista hyötyä. Sedimentti saattaa päinvastoin alentaa pellon helppoliukoisen fosforin pitoisuutta. Tämän tutkimuksen perusteella laskeutusallas-kosteikkosedimentin laajamittaista levitystä peltoon ei suositella. Pienien määrien levityksessä on huomioitava, ettei sedimentin osuus nouse yli $10 \%$ kasvualustan määrästä, joka tarkoittaa noin $200 \mathrm{~m}^{3}$ sedimenttiä hehtaaria kohden kyntökerrokseen muokattuna.

Eroosioprosessin olosuhdemuutokset vaikuttavat oleellisesti fosforin pidättymiseen tai vapautumiseen. Vesieroosiossa peltomaan helppoliukoisesta fosforifraktiosta vapautuu valumaveteen fosforia ja liukoisena se todennäköisesti huuhtoutuu alapuoliseen vesistöön. Pääosin savesta oleva hienojakoinen eroosioaines 
sedimentoituu laskeutusaltaan pohjalle mukanaan suuri Fe-oksideihin sitoutunut fosforifraktio. Olosuhteiden muuttuessa hapettomiksi kosteikon pohjalla Fe pelkistyy ja oksideja liukenee, jolloin niihin sitoutunutta fosforia vapautuu veteen. Sedimentin hapettuessa uudelleen, esimerkiksi peltolevityksessä, Fe-oksidit muodostavat runsaasti uutta pidätyspintaa, mikä lisää maa-aineksen fosforinsitomiskykyä huomattavasti. Tämän tutkimuksen perusteella myös lannoitefosforia saattaa sitoutua kasvien ulottumattomiin uudelle oksidipinnalle, jota syntyy sedimentin hapettumisen seurauksena, jos sedimenttiä levitetään peltoon.

\section{Kiitokset}

Tätä tutkimusta rahoittaa MMM/MAKERA.

\section{Kirjallisuus}

Hartikainen, H. 1979. Phosphorus and its reactions in terrestrial soils and lake sediments. Journal of the Scientific Agricultural Society of Finland 51: 537-624.

Kaila, A. 1964. Fractions of inorganic phosphorus in Finnish mineral soils. The Journal of the Scientific Agricultural Society of Finland 36: 1-13.

Puustinen, M., Koskiaho, J., Jormola, J., Järvenpää, L., Karhunen, A., Mikkola-Roos, M., Pitkänen, J., Riihimäki, J., Svensberg, M. \& Vikberg, P. 2007. Maatalouden monivaikutteisten kosteikkojen suunnittelu ja mitoitus. Suomen ympäristö 21. $80 \mathrm{~s}$.

Uusitalo, R. \& Ekholm, P. 2003. Phosphorus in runoff assessed by anion exchange resin extraction and an algal assay. Journal of Environmental Quality 32: 633-641.

Uusitalo, R. \& Turtola, E. 2003. Determination of redox-sensitive phosphorus in field runoff without sediment preconcentration. Journal of Environmental Quality 32 1: 70-77.

Schwertmann U. (1964). The differentiation of iron oxides in soil by extraction with ammonium-oxalate solution. Zeitschrift fur Pflanzenernahrung, Dungung und Bodenkunde, 105: 194-202.

Sibbesen, E. 1978. An investigation of the anion-exchange resin method for soil phosphate extraction. Plant Soil 50: 305-321. 